\title{
Nephrolithiasis (part 1): Epidemiology, causes and pathogenesis of recurrent nephrolithiasis
}

\author{
A M Meyers, ${ }^{1,2}$ FCP (SA), Cert Nephrology (SA), FRCP (Lond) MD; \\ S Naicker, ${ }^{2} \mathrm{MB}$ ChB, MRCP (UK), FRCP (Lond), FCP (SA), PhD \\ ${ }^{1}$ Division of Nephrology, Department of Internal Medicine, Faculty of Health Sciences, University of the Witswatersrand, Johannesburg, South Africa \\ ${ }^{2}$ National Kidney Foundation of South Africa, Johannesburg, South Africa
}

Corresponding author: A M Meyers (nkfsa@mweb.co.za)

A recent increase in the incidence of recurrent renal calcium oxalate calculi has been demonstrated. Although a few advances have shown that the increase in incidence of these stones is due to genetic causes, it is mostly associated with a change in environmental factors. Global warming and weather changes, some medications administered to young children and eating habits play a pivotal role in increasing stone incidence. By far the most important single factor in stone incidence involves the increased ingestion of red meat and salt. So much so that it is anticipated that calcium oxalate stone occurrence will increase pari passu with dietary changes in the South African black community. The reasons for the difference in the incidence between males and females ( $12 \% \mathrm{v} .6 \%)$ remain controversial, and should be further studied.

S Afr Med J 2021;111(10):930-933. https://doi.org/10.7196/SAMJ.2021.v111i10.15988

Kidney stone disease is commonly seen in general practice in both children and adults. This review addresses the epidemiology, causes, pathogenesis, diagnosis and management of recurrent nephrolithiasis, and the data reviewed in this article are taken from experience gained from running a kidney stone clinic for 40 years, which culminated in the publication of an MD thesis entitled 'The pivotal role of a kidney stone clinic in the management and prevention of recurrent calcium oxalate nephrolithiasis. ${ }^{[1]}$ The thesis is considerably more detailed than the review, and is available to those who wish to further their reading on the subject.

\section{Epidemiology}

Renal calculous disease was known in the days of Hippocrates (400 BCE). The era of the alchemists started in about $1200 \mathrm{BCE}$, and the barber surgeons from about 1400 - 1700 BCE. The alchemists diagnosed the causes of kidney disorders as well as kidney stones based on the colour, composition, odour and taste of multiple urine samples to which chemicals had been added. They were then able to 'treat' their patients. The victims of the barber surgeons seldom survived after attempts to remove renal, ureteric and bladder calculi. Hence a saying proposed many years before by Hippocrates, 'Thou shalt not cut for stone, was brought into law. ${ }^{[2]}$

Stone disease is still one of the most common conditions seen in medical practice. It is associated with considerable mortality, chronic kidney disease (CKD) and occasionally even end-stage kidney disease (ESKD). ${ }^{[3-5]}$ In 2001, nephrolithiasis was estimated to occur in about $12 \%$ of males and $5 \%$ of females. Multiple recurrences were seen in $\sim 50 \%$ of these individuals. ${ }^{[6,7]}$ Calcium oxalate $(\mathrm{CaOx})$ calculi have been found to be the cause of stones in $>80 \%$ of stone patients, and are frequently recurrent. Renal $\mathrm{CaOx}$ calculi occur in $85 \%$ of cases, and in the other $15 \%$, calcium phosphate $(\mathrm{CaP})$ comprises the chemical make-up. These CaP calculi occasionally cause ESKD.

$\mathrm{CaOx}$ calculi are rare in the South African (SA) black population and in African Americans. The introduction of Westernised diets in recent years is expected to increase stone formation, but by a small margin only. As has been shown in African Americans, genetic factors occur that significantly inhibit the precipitation of $\mathrm{CaOx}$ in the urine. Although not yet studied in the black SA population, similar genetic findings remain a distinct possibility. ${ }^{[8-10]}$ Moreover, as the years progress, so does stone incidence increase - especially in children. This is well illustrated in Fig. 1, and the epidemiological causes are for further reading, as discussed in the references. ${ }^{\text {[11-14] }}$

Note:

- There has been an increase in incidence in all age groups - mostly in those aged 10 - 19 years (23\%).

- The mean incidence in African Americans is 15\% (stone type not specified).

- There are no data in black South Africans. CaOx calculi are still $\operatorname{rare}(\sim 1 \%){ }^{[11]}$

\section{Causes of nephrolithiasis}

Major risk factors related to stone formation are shown in Fig. 2. These can include medullary sponge kidney, horseshoe kidney and autosomal dominant polycystic kidney disease.

These factors interact with one another, and are self-explanatory. The general aspects of different types of stone are shown in Table 1 . This table clearly indicates how important it is to have the kidney

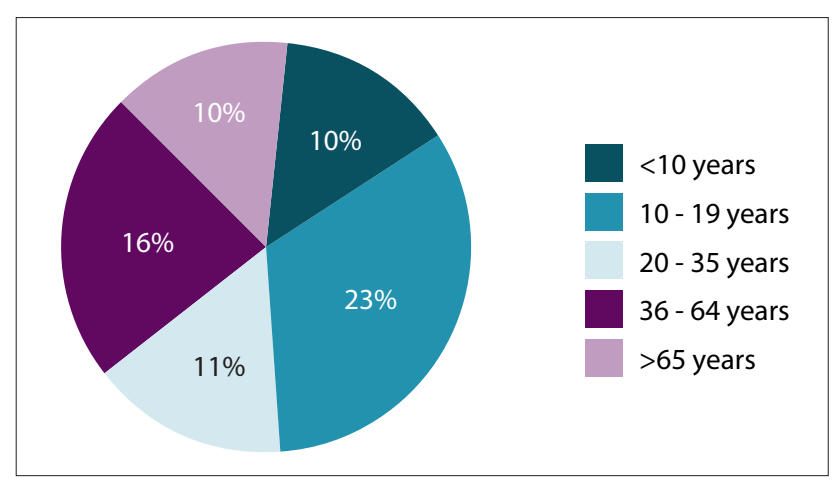

Fig. 1. Percentage changes in incidence of stone formation according to age groups. (Data extracted from Tasian et al. ${ }^{[11]}$ ) 


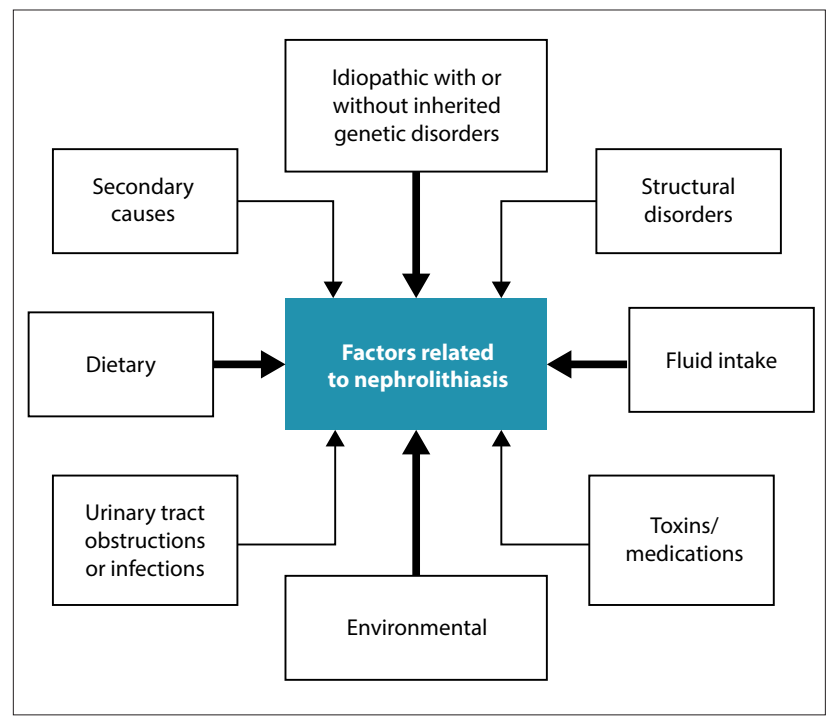

Fig. 2. The major general risk factors in the development of kidney stones. (Reproduced with permission from Meyers. ${ }^{[1]}$ ) stone chemically analysed. It is recommended that all first stones be analysed, and on one or occasionally two occasions, recurrent calculi should also be analysed. Stone analysis is often omitted by practitioners.

The causes of secondary stones are shown in Table 2.

\section{Pathogenesis of nephrolithiasis}

Stone formation is a multistep process comprising crystal nucleation, growth, aggregation and finally, agglomeration. ${ }^{[21-26]}$ It is a highly complex process, and only the basic steps are illustrated in Figs 3 and 4 .

There are three steps in the process of crystallisation. Before a stone is formed, either nuclei or aggregates of nuclei must stick together. This is the process of crystallisation, and depends on the composition and concentration of urinary solutes. Then they must enlarge to form an agglomerate (i.e. a microcalculus). This process is ordered by the chemical process of 'epitaxy' (sticking together) in stone formers' urines. $\mathrm{CaOx}$ stones can also form in association with 'hyperuricosuria' when epitaxy is absent; 'salting out' is the mechanism. ${ }^{[7]}$

Metastable limit can also be lower in acid urines $(\mathrm{pH}<5.5)$. This is because of the ability of uric acid to cause precipitation of $\mathrm{CaOx}$ by

Table 1. General aspects related to the formation of different types of renal calculi ${ }^{[15-20]}$

\begin{tabular}{lll}
\hline Stone type & Urinary risk factor & Clinical aspect \\
\hline Calcium oxalate monohydrate & Hypercalciuria & Idiopathic \\
& & Salt excess \\
& Hyperparathyroidism \\
& & Excess vitamin $\mathrm{D}$ \\
& & Sarcoid and other granulomas \\
& & Genetic (e.g. Cushing's disease, \\
Calcium oxalate monohydrate & Hyperoxaluria & Dent's disease and similar hypercalciuric disorders) \\
& & Genetic hyperoxaluria \\
& & Idiopathic \\
Calcium phosphate & & Bowel pathology \\
& & Excess vitamin C \\
Struvite & & As for calcium oxalate monohydrate \\
Cystine & & Distal renal tubular acidosis \\
& & Drugs, e.g. acetazolamide, topiramate
\end{tabular}

\section{Table 2. Important secondary causes of nephrolithiasis ${ }^{[15-20]}$}

\begin{tabular}{ll}
\hline Cause & Biochemical change \\
\hline Primary hyperparathyroidism & Hypercalcaemia/hypercalciuria \\
Sarcoidosis & Hypercalcaemia (10\%), hypercalciuria (80\%) \\
Other granulomas & Hypercalcaemia, hypercalciuria \\
Genetic & \\
$\quad \begin{array}{l}\text { Primary hyperoxaluria (all three subtypes) } \\
\text { Cystinuria }\end{array}$ & $\begin{array}{l}\text { Hyperoxaluria ( }>1000 \mu \text { mol/24 hours) } \\
\text { Cystine and other dibasic amino acidurias }\end{array}$ \\
$\begin{array}{l}\text { Tubulopathies } \\
\text { Type I renal tubular acidosis }\end{array}$ & $\begin{array}{l}\text { Hyper/normocalcaemia, hypomagnesaemia, hypomagnesuria, } \\
\text { hypocalciuria }\end{array}$ \\
Ulcerative colitis & Hypercalciuria, hypocitraturia, systemic acidosis, urine pH $>5.3$ \\
Crohn's disease & Hyperoxaluria, hypocitraturia, hyperuricaemia, hyperuricosuria, low \\
Other chronic diarrhoeas & urine volume, hypomagnesaemia and hypomagnesuria \\
Post-bariatric surgery & Hyperoxaluria \\
Cushing's syndrome (primary or post-steroid ingestion) & Hypercalcaemia/hypercalciuria
\end{tabular}


the technique of salting out, even in the presence of adequate levels of other inhibitors.

These steps, as illustrated, are modified by factors that either promote or inhibit stone formation, as shown in Table 3. Major metabolic and mineral pathogenic factors are discussed in both groups.

\section{Promotion}

Of all the multiple factors, adequate water intake plays a pivotal role.

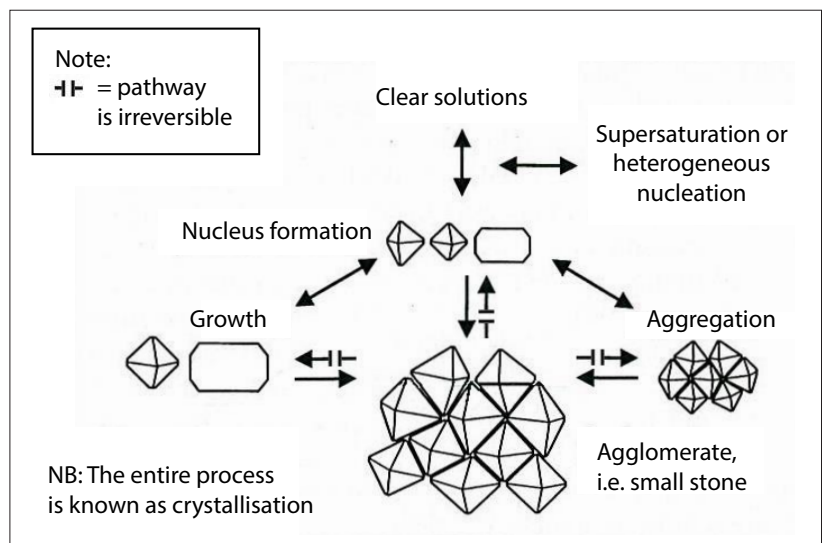

Fig. 3. The process of crystallisation. (Adapted with permission from Meyers and Martins. ${ }^{[7]}$ )

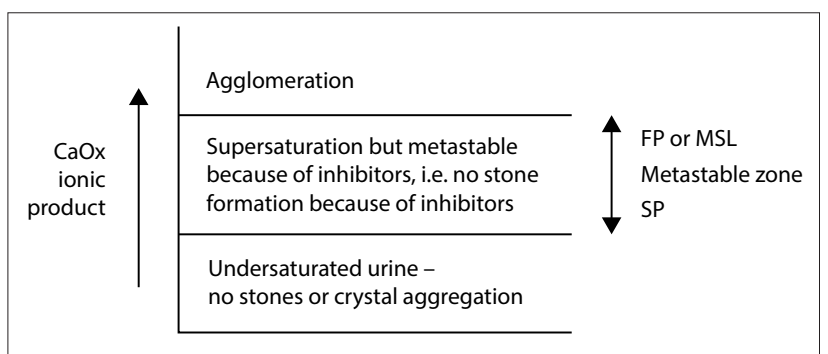

Fig. 4. Precipitation of calcium oxalate crystals with stone formation in either whole urine or a similarly manufactured solution. ( $\mathrm{CaOx}=$ calcium oxalate; $F P=$ formulation product $; M S L=$ metastable limit $; S P=$ saturation product.) (Reproduced with permission from Meyers and Martins. ${ }^{\left[{ }^{[7]}\right)}$
Dehydration from any cause of water deprivation will render the urine lithogenic, while a good urine output (at least $2.4 \mathrm{~L}$ per day in recurrent stone formers) will constitute a significant inhibitory force. Fig. 5 demonstrates the effect of a low sodium diet on the 24-hour urinary calcium excretion.

The sources of dietary salt excess are dealt with under the management section (part 2). Basically, the World Health Organization recommends a daily sodium chloride intake of $5-5.5 \mathrm{~g}$ per day. This would ensure that the 24-hour urinary sodium excretion would be in the region of $80-100 \mathrm{mmol}$. Unfortunately, modern man is under such marketing persuasion that the usual excretion is $140-180 \mathrm{mmol}$ per 24 hours. Stone formers' excretions are often much higher, and even exceed $300 \mathrm{mmol}$ per day. We are 'pickling ourselves in brine'.

The other important promotors are calcium (Ca) (hypercalciuria), hyperuricosuria and hyperoxaluria. By far the most common cause of hypercalciuria is an excessive amount of dietary salt.

Of pivotal importance in $\mathrm{CaOx}$ stone formation is the effect that urinary uric acid has on $\mathrm{CaOx}$ precipitation. By increasing the concentration of urinary uric acid, the uric acid will precipitate $\mathrm{CaOx}$ crystal formation via a chemical mechanism called salting out. ${ }^{[27]}$ Simplistically, the uric acid acts as a catalyst for $\mathrm{CaOx}$ precipitation to form $\mathrm{CaOx}$ stones. If the urine is acid (as is common in the red meateating population), this salting out can occur even with normal urinary uric acid concentrations. There is a large body of research to suggest that allopurinol should be used in frequent $\mathrm{CaOx}$ stone formers.

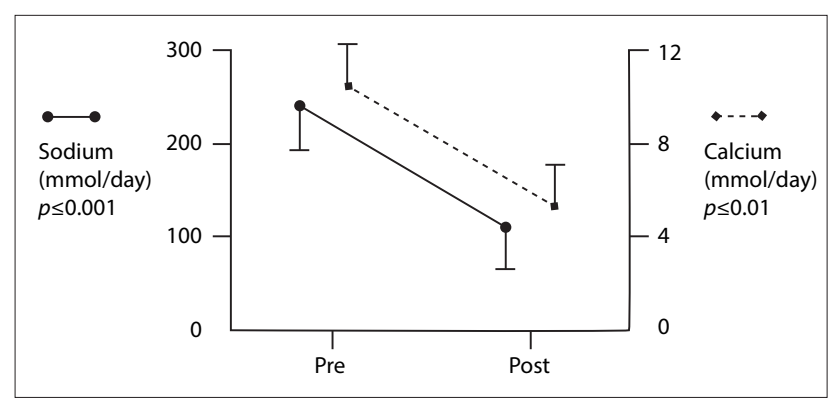

Fig. 5. 24-hour urine sodium and calcium in recurrent calcium stone formers pre-and post-standard (i.e. 'healthy') sodium diet (100 mmol/day). (Reproduced with permission from Meyers and Martins. ${ }^{[7]}$ )

Table 3. Promotors and inhibitors of stone formation ${ }^{[6]}$

\begin{tabular}{ll} 
Table 3. Promotors and inhibitors of stone formation ${ }^{[6]}$ & Inhibitor \\
\hline Promotor & Inorganic \\
Low urine volume & Water \\
Failure of adequate intake & Magnesium \\
& Pyrophosphate \\
& Citrate \\
Global and regional climate change & Organic \\
& Nephrocalcin \\
& F-1 fragment of prothrombin \\
& Sulphated glycosaminoglycans \\
Calcium (including the role of sodium) & Tetrahydropalmatine (Tamm-Horsfall protein) \\
Urate & \\
Oxalate & \\
Low urinary pH & \\
Cystine & \\
Antibiotics & \\
Bacterial products (not for recurring calcium oxalate stone formation) & \\
Proton pump inhibitors &
\end{tabular}


This applies whether or not there is hyperuricaemia, which is always associated with even a mild rise in the urinary uric acid concentration (which could occur if the patient were dehydrated). ${ }^{[28,29]}$

\section{Inhibition}

The role of water in urinary dilution has already been mentioned. Hypomagnesaemia and hypomagnesuria may occasionally be found in children with genetic renal dysfunction, e.g. renal tubular acidosis (RTA), or in secondary causes of tubular dysfunction. Magnesium is a potent inhibitor of $\mathrm{CaOx}$ precipitation and plays an important role in these patients and in stone formation.

In the white SA population, a decrease of the 24-hour urinary citrate level is by far the most common pathogenetic factor in the production of recurrent $\mathrm{CaOx}(\mathrm{RCaOx})$ stone disease. This has not been found in black South Africans. ${ }^{[30]}$ Other secondary risk factors for hypocitraturia include diets low in potassium, and any cause (whether primary or secondary) of RTA. Of importance is the RTA associated with the use of acetazolamide and topiramate (Topamax). ${ }^{[31]}$

\section{Other factors in the pathogenesis of $\mathrm{CaOx}$ stone formation}

Several dietary factors exist, which will be dealt with under the section on management (part 2).

There is a definite association between obesity and $\mathrm{CaOx}$ stone formation. This may in part be ascribed to dietary indiscretion, but other metabolic factors also play an important role. ${ }^{[32-35]}$

The frequent presence of Randall's plaques in recurrent stone formers is an important epidemiological as well as pathogenetic factor in the production of recurrent stone formation. ${ }^{[36-43]}$ Randall's plaques increase in number and form in the tips of the papillae in recurrent stone formers. They are diagnosed by radiological techniques. In the black population of SA, Randall's plaques seem to be far less frequent or almost absent, but future studies are required to confirm these observations. This is yet another reason for decreased stone formation in black patients.

The frequent misuse of antibiotics, especially in children, has been shown to be a risk factor in $\mathrm{CaOx}$ stone production. ${ }^{[14]}$

\section{Declaration. None.}

Acknowledgements. None.

Author contributions. Concept, design and authorship: AMM. Support, major editing and many suggestions in main reference ${ }^{[1]}$ that formed the basis of this presentation: SN.

Funding. None.

Conflicts of interest. None.

1. Meyers AM. The pivotal role of a kidney stone clinic in the management and prevention of recurrent calcium oxalate nephrolithiasis. Wits Institutional Repository on DSpace, 2020. http://wiredspace.wits. ac.za/browse?authority=77f47495-e38c-4841-9362-428505767a29\&type=author (accessed 7 July 2021). 2. Poulakou-Rebelakou E, Rempelakos A, Tsiamis C, Dimopoulos C. 'I will not cut, even for the stone' Origins of urology in the Hippocratic collection. Int Braz J Urol 2015;41(1):26-29. https.//doi org/10.1590/S1677-5538.IBJU.2015.01.05

3. Gambaro G, Favaro S, D’Angelo A. Risk for renal failure in nephrolithiasis. Am J Kidney Dis 2001;37(2):233-243. https://doi.org/10.1053/ajkd.2001.21285

4. Gillen DL, Worcester EM, Coe FL. Decreased renal function among adults with a history of nephrolithiasis: A study of NHANES III. Kidney Int 2005;67(2):685-690. https://doi.org/10.1111/j.15231755.2005.67128.x

5. Rule AD, Krambeck AE, Lieske JC. Chronic kidney disease in kidney stone formers. Clin J Am Soc Nephrol 2011;6(8):2069-2075. https://doi.org/10.2215/CJN.10651110
6. Bihl G, Meyers A. Recurrent renal stone disease - advances in pathogenesis and clinical management. Lancet 2001:358(9282):651-656. https://doi. org/10.1016/S0140-6736(01)05782-8

7. Meyers AM, Martins MC. Arthur Landau Lecture 2000: Recurrent calcium oxalate renal calculi - a meyers AM, Martins MC. Arthur Landau Lecture 2000: Recurrent cal
medically preventable disorder. Trans J Coll Med S Afr 2001;45(1):23-28.

medically preventable disorder. Trans J Coll Med S Afr 2001;45(1):23-28.
8. Sarmina I, Spirnak JP, Resnick MI. Urinary lithiasis in the black population: An epidemiological study 8. Sarmina I, Spirnak JP, Resnick MI. Urinary lithiasis in the black population: An epidemiological st
and review of the literature. J Urol 1987;138:14-17. https://doi.org/10.1016/s0022-5347(17)42971-5

and review of the literature. J Urol 1987;138:14-17. https://doi.org/10.1016/s0022-5347(17)42971-5
9. Seifert-McLean CM, Cromer BA, Mosher G, Mahan JD. Urinary calcium excretion in healthy adolescents. J Adolesc Health Care 1989;10:300-304. https://doi.org/10.1016/0197-0070(89)90061-2

10. Stamatelou KK, Francis ME, Jones CA, Nyberg LM, Curhan GC. Time trends in reported prevalence of . Stamatelou KK, Francis ME, Jones CA, Nyberg LM, Curhan GC. Time trends in reported prevalence of
kidney stones in the United States: 1976 - 1994. Kidney Int 2003;63:1817-1823. https://doi.org/10.1046/ $1523-1755.2003 .00917$.

11. Tasian GE, Ross ME, Song L, et al. Annual incidence of nephrolithiasis among children and adults in South Carolina from 1997 to 2012. CJASN 2016;11(3):488-496. https://doi.org/10.2215/CJN.07610715

12. Brikowski TH, Lotan Y, Pearle MS. Climate-related increase in the prevalence of urolithiasis in the United States. Proc Natl Acad Sci USA 2008;105(28):9841-9846. https://doi.org/10.1073/pnas.0709652105

13. Tasian GE, Pulido JE, Gasparrini A, et al. Daily mean temperature and clinical kidney stone presentation in five US metropolitan areas: A time-series analysis. Environ Health Perspect 2014;122(10):1081-1087. https://doi.org/10.1289/ehp.1307703

14. Tasian GE, Jemielita T, Goldfarb DS, et al. Oral antibiotic exposure and kidney stone disease. JASN 2018;29(6):1731-1740. https://doi.org/10.1681/ASN.2017111213

15. Goodyer P, Saadi I, Ong P, Elkas G, Rozen R. Cystinuria subtype and the risk of nephrolithiasis. Kidney Int 1998;54:56-61. https://doi.org/10.1046/j.1523-1755.1998.00957.x

16. Coe FL, Worcester EM, Evan AP. Idiopathic hypercalciuria and formation of calcium renal stones. Nat Rev Nephrol 2016;12(9):519-533. https://doi.org/10.1038/nrneph.2016.101

17. Alelign T, Petros B. Kidney stone disease: An update on current concepts. Adv Urol 2018:3068365. https://doi.org/10.1155/2018/3068365

18. Gambaro G, Vezzoli G, Casari G, Rampoldi L, D’Angelo A, Borghi L. Genetics of hypercalciuria and calcium nephrolithiasis: From the rare monogenic to the common polygenic forms. Am J Kidney Dis 2004;44(6):963-986. https://doi.org/10.1053/j.ajkd.2004.06.030

19. Strauss SB, Waltuch T, Bivin W, Kaskel F, Levin TL. Primary hyperoxaluria: Spectrum of clinical and imaging findings. Pediatr Radiol 2017;47(1):96-103. https://doi.org/10.1007/s00247-016-3723-7

20. Worcester EM, Coe FL. Nephrolithiasis. Prim Care 2008;35(2):369-391. https://doi.org/10.1016/j. pop. 2008.01 .005

pop.2008.01.005
21. Pfau A, Knauf F. Update on nephrolithiasis: Core curriculum 2016. Am J Kidney Dis 2016;68(6):973-985. https://doi.org/10.1053/j.ajkd.2016.05.016
hatis

22. Khan SR, Hackett RL. Role of organic matrix in urinary stone formation: An ultrastructural study of Khan SR, Hackett RL. Role of organic matrix in urinary stone formation: An ultrastructural study of
crystal matrix interface of calcium oxalate monohydrate stones. J Urol 1993;150(1):239-245. https://doi. crystal matrix interface of calcium oxa
org/10.1016/s0022-5347(17)35454-x

23. Linnes MP, Krambeck AE, Cornell L, et al. Phenotypic characterisation of kidney stone formers by endoscopic and histological quantification of intrarenal calcification. Kidney Int 2013;84(40):818-825. https://doi.org/10.1038/ki.2013.189

24. Wesson JA, Ward MD. Role of crystal surface adhesion in kidney stone disease. Curr Opin Nephrol Hypertension 2006;15(4):386-393. https://doi.org/10.1097/01.mnh.0000232879.50716.6f

25. Sokol E, Nigmatulina E, Maksimova N, Chiglintsev A. CaC2O4H2O spherulites in human kidney stones: Morphology, chemical composition, and growth regime. Eur J Mineral 2005;17:285-295. https://doi. org/10.1127/0935-1221/2005/0017-0285

26. Lindberg JS, Cole FE, Romani W, et al. Calcium oxalate stone agglomeration inhibition [tm] reflects renal stone-forming activity. Ochsner J 2000;2(2):68-78

27. Ryall RL, Hibberd CM, Marshall VR. A method for studying inhibitory activity in whole urine. Urol Res 1985;13:285-289. https://doi.org/10.1007/BF00262658

28. Ettinger B, Tang A, Citron JT, Livermore B, Williams T. Randomised trial of allopurinol in the prevention of calcium oxalate calculi. N Engl J Med 1986;315(22):1386-1389. https://doi.org/10.1056/ NEJM198611273152204

29. Culleton BF, Larson MG, Cannel WB, et al. Serum uric acid and risk for cardiovascular disease and death: The Framingham Heart Study. Kidney Int 1999;65(3):1041-1049.

30. Whalley NA, Moraes MF, Shar TG, Pretorius SS, Meyers AM. Lithogenic risk factors in the urine of black and white subjects. Br J Urol 1998;82(6):785-790. https://doi.org/10.1046/j.1464-410x.1998.00877.x

31. Zuckerman JM, Assimos DG. Hypocitraturia: Pathophysiology and medical management. Rev Urol 2009;11(3):134-144. https://doi.org/10.3909/riu0424

32. Siener R, Glatz S, Nicolay C, Hesse A. The role of overweight and obesity in calcium oxalate stone formation. Obes Res 2004;12(1):106-113. https://doi.org/10.1038/oby.2004.14
fority

33. Del Valle EE, Negri AL, Spivacow FR, Rosende G, Forrester M, Pinduli I. Metabolic diagnosis in stone 3. Del Valle EE, Negri AL, Spivacow FR, Rosende G, Forrester M, Pinduli I. Metabolic diagnosis in stone
formers in relation to body mass index. Urol Res 2012;40(1):47-52. https://doi.org/10.1007/s00240-011formers

34. Curhan GC, Willett WC, Rimm EB, Speizer FE, Stampfer MJ. Body size and risk of kidney stones. J Am Soc Nephrol 1998;9(9):1645-52. https://www.ncbi.nlm.nih.gov/pubmed/9727373

35. Taylor EN, Stampfer MJ, Curhan GC. Obesity, weight gain, and the risk of kidney stones. JAMA 2005;293(4):455-462. https://doi.org/10.1001/jama.293.4.455

36. Randall A. The origin and growth of renal calculi. Ann Surg 1937;105(6):1009-1027. https://doi. org/10.1097/00000658-193706000-00014

37. Randall A. Papillary pathology as a precursor of primary renal calculus. J Urol 1940;44:580-589. https:// doi.org/10.1016/S0022-5347(17)71305-5

8. Tiselius HG, Ackermann D, Alken P, Buck C, Conort P, Gallucci M. Guidelines on Urolithiasis 1. Eur Urol 2001;40:362-371. https://doi.org/10.1159/000049803

39. Evan AP, Lingeman JE, Coe FL, et al. Randall's plaque of patients with nephrolithiasis begins in basement membranes of thin loops of Henle. J Clin Invest 2003;111(5):607-616. https://doi.org/10.1172/ JCI200317038

. Evan A, Lingeman J, Coe FL, Worcester E. Randall's plaque: Pathogenesis and role in calcium oxalate nephrolithiasis. Kidney Int 2006;69(8):1313-1318. https://doi.org/10.1038/sj.ki.5000238

1. Chung HJ. The role of Randall plaques on kidney stone formation. Transl Androl Urol 2014;3(3):251-254. https://doi.org/10.3978/j.issn.2223-4683.2014.07.03

42. Abrol N, Kekre NS. Revisiting Randall's plaque. Afr J Urol 2014;20(4):174-179. https://doi.org/10.1016/j. afju.2014.06.001

43. Khan SR, Pearle MS, Robertson WG, et al. Kidney stones. Nat Rev Dis Primers 2016;2:16008. https:// doi.org/10.1038/nrdp.2016.

Accepted 29 July 2021 